\title{
Long-term Performance of Pecan Trees when Potassium Application Is Based on Prescribed Threshold Concentrations in Leaf Tissue
}

\author{
Ray E. Worley ${ }^{1}$ \\ Department of Horticulture, University of Georgia, Coastal Plain Experiment Station, Tifton, \\ GA 31793-0748
}

Additional index words. leaf analysis, Carya illinoensis, fertilizer

\begin{abstract}
Potassium was applied to old 'Stuart' pecan [Carya illinoensis (Wagenh.) C. Koch] trees only when leaf concentrations dropped below thresholds of $0.25,0.50,0.75$, or $1.00 \% \mathrm{~K}$ or annually, regardless of leaf $\mathrm{K}$. Depletion of $\mathrm{K}$ was extremely slow, with soil K concentrations remaining at 68 to $168 \mathrm{~kg} \cdot \mathrm{ha}^{-1}$ (medium) or higher in the 0 to 15 and 15 to $30 \mathrm{~cm}$ depths after 20 years without $\mathrm{K}$ application. No trees were below the $0.25 \%$ leaf $\mathrm{K}$ threshold over the 20 -year period. Yield, tree growth, nut quality, and tree appearance were similar for all K treatments. A leaf $\mathrm{K}$ threshold of $0.75 \%$ seemed adequate and practical for the low end of the sufficiency range.
\end{abstract}

Several studies (Blackmon, 1936; Fowler et al., 1933; Hammar and Hunter, 1948; Hunter and Hammar, 1947, 1948; Skinner, 1921, 1922, 1923, 1926, 1927; Skinner and Ruprecht, 1926) demonstrated the benefits of applying complete fertilizers to pecan trees. Many studies (Gammon and Sharpe, 1959; Hunter, 1956; Hunter and Hammar, 1947, 1948; Sharpe et al., 1950, 1952; Worley, 1974), however, did not show a yield increase from K applications. Pecan yields were not affected by K applications when soil $\mathrm{K}$ concentration was $\geq 67 \mathrm{~kg} \cdot \mathrm{ha}^{-1}$ (Worley, 1974).

Trees did not respond to $\mathrm{K}$ applications when soils had abundant $\mathrm{K}$ or if orchards received liberal applications in preceding years. It is logical to determine the sufficiency range for leaf $\mathrm{K}$ and apply K only when leaf concentrations indicate a shortage. A leaf analysis program was initiated in Georgia in 1965. Many states now offer leaf analysis to pecan growers. The lower threshold of the sufficiency range for pecan leaf analysis needs further refinement. Many studies have shown leaf analysis responses to $\mathrm{K}$ applications (Gammon and Sharpe, 1959; Sharpe et al., 1950; Smith et al., 1985; Worley, 1990b), and most pecan-belt states recommend $\mathrm{K}$ applications based on leaf analysis; however, no reports were found that evaluated the minimum $\mathrm{K}$ sufficiency concentration with applications made in this manner for several years. Georgia currently uses a sufficiency range of $0.75 \%$ to $2.50 \% \mathrm{~K}$ (Plank, 1988). Georgia pecan growers leaf samples in 1989 ranged as follows: $<0.75 \%=1 \%, 0.75$ to $1.00 \%=17 \%, 1.01$ to $1.25 \%=36 \%, 1.26$ to $1.50 \%=36 \%,>1.50 \%=10 \%$ (Owen Plank, personal communication). These data suggest that Georgia pecan growers may be applying more $\mathrm{K}$ than necessary. Upson and Sparks (1969) found that pecan seedlings in the greenhouse grew normally at leaf $\mathrm{K}$ concentrations between $0.98 \%$ and $3.75 \%$, but if no $\mathrm{K}$ was included in the nutrient solution, leaves showed $\mathrm{K}$ deficiency symptoms when leaf concentrations were $0.30 \%$, thus indicating that the lower threshold is between $0.30 \%$ and $0.98 \%$. A field study (Worley, 1974) obtained K deficiency symptoms at leaf concentrations of $0.58 \%$ when no $\mathrm{K}$ was applied for several years, although yield was not reduced. Since deficiency symptoms occurred, it is assumed that the lower threshold should be

Received for publication 26 Apr. 1993. Accepted for publication 20 Sept. 1993. The cost of publishing this paper was defrayed in part by the payment of page charges. Under postal regulations, this paper therefore must be hereby marked advertisement solely to indicate this fact.

${ }^{1}$ Professor of horticulture. higher than $0.58 \%$.

This study tests the effects of soil K applications on pecan trees made only when leaf concentrations dropped below specified thresholds. It also attempted to determine the optimum leaf $\mathrm{K}$ concentration for the lower threshold of the sufficiency range and document $\mathrm{K}$ depletion rates in pecan orchards. Variables measured were yield, nut quality, tree growth, tree appearance, and leaf and soil elemental concentrations. A recent study (Worley, 1990a) reported the long-term performance of pecan trees when $\mathrm{N}$ applications were made based on leaf analysis. This is a similar study in which K applications were based on leaf $\mathrm{K}$ analysis over a 20-year period.

\section{Materials and Methods}

The study was initiated in 1973 on mature (>50-year-old) 'Stuart' pecan trees in a separate portion of the orchard used for the N study reported earlier (Worley, 1990a). The soil was a Tifton loamy sand (Ultisol Plintic Paleodults: fine loamy silicious, thermic) located near Tifton, Ga. (lat. $\approx 31.3^{\circ} \mathrm{N}$, long. $83.6^{\circ} \mathrm{W}$ ). The current study includes the years $1973-92$. Leaf concentration of the elements was determined by collecting 50 middle leaflets from middle leaves from terminals in the area of maximum limbspread of each tree ( $\approx 6$ to $9 \mathrm{~m}$ high) between the second week of July and the first week of August each year (Plank, 1988). No nutrient sprays were applied, and leaves were visually clean and were not washed. Leaves were dried, ground to 20 mesh, and duplicate $1-\mathrm{g}$ samples were analyzed for $\mathrm{N}$ by a macro-Kjeldahl procedure (Horwitz, 1980). Also, duplicate 1-g samples were ashed at $\approx 450 \mathrm{C}$ in a muffle furnace; the ash then was dissolved in $1.5 \mathrm{~N} \mathrm{HNO}_{3}$, diluted, and $\mathrm{P}$ was determined colorimetrically by developing a yellow, vanadomolybdophosphoric acid color from the ash extract. Leaf $\mathrm{K}, \mathrm{Ca}, \mathrm{Mg}, \mathrm{Fe}, \mathrm{Mn}, \mathrm{Zn}$, and $\mathrm{Cu}$ were determined from the ash extract by atomic absorption spectrophotometry. Nutrients in soil were determined from a composite of 12 soil plugs taken in winter from under the canopy of each tree. Samples were divided into 0 to 15 and 15 to $30 \mathrm{~cm}$ depths, dried, and analyzed for $\mathrm{pH}$ (water), $\mathrm{P}, \mathrm{K}, \mathrm{Ca}$, and $\mathrm{Mg}$ (double-acid extractant) by the procedures of Cahoon (1974). The soil test results are a measure of the residual extractable nutrients at the end of the growing season and before the next season's fertilizer was applied; therefore, data reported for a particular year might have been taken early in the succeeding year. 
Current season's terminal shoot growth was measured and crop density (number of fruit per terminal) was made in the same area of the tree canopy and at the same time that leaf samples were collected. Twenty-five adjacent terminals were measured on each quadrant of the tree (100/tree) and the fruit (nutlets) present on the 25 terminals were counted. Trunk circumference was measured annually in the area of minimum circumference between the root flange and the first limb. Vigor and leaf color ratings were made visually for each tree in fall using an arbitrary rating of 1 to $9(1=$ lowest vigor-color, 9 = highest vigor-color).

Nuts harvested from individual trees were weighed each year and quality determinations were made from a 50 -nut $(\approx 0.5-\mathrm{kg})$ sample. The in-shell nut sample was weighed and graded into size classifications by $0.16-\mathrm{cm}$ increments of diameter. Edible kernels were graded into fancy, standard, and amber color grades used by Goldkist Pecan Co., and percentages (of in-shell nut) of each grade, total percentage kernel, and nuts per kilogram were calculated. Edible kernels with defects and dark kernels were placed in the amber grade. Brightest kernels were graded fancy. Nuts from the orchard were consolidated and sold locally to the highest bidder each year. The average price paid for all 'Stuart' pecans bought each year by a prominent pecan buyer-sheller based on kernel yield was used to calculate value of the nuts for 1973-77. In subsequent years the actual price received for the consolidated lot was used to calculate the value of nuts from each treatment. This value did not reflect differences in price that might have been obtained due to kernel grade or nut size, since all the nuts were sold as one lot.

Treatments were constructed so that $93 \mathrm{~kg} \cdot \mathrm{ha}^{-1}$ of $\mathrm{K}$ from muriate of potash was applied on an individual tree basis only when the previous season's leaf $\mathrm{K}$ concentration for that tree was $<0.25 \%$ (K 0.25), $0.50 \%$ (K 0.50), $0.75 \%$ (K 0.75$)$, or $1.00 \%$ (K 1.00). An additional treatment added $93 \mathrm{~kg} \cdot \mathrm{ha}^{-1}$ of $\mathrm{K}$ annually regardless of leaf analysis (AK). All trees received a uniform annual application of $112 \mathrm{~kg} \cdot \mathrm{ha}^{-1}$ of $\mathrm{N}$, and dolomitic limestone was added five times to maintain the soil $\mathrm{pH}$ near 6.0. Zinc was soil applied to individual trees if leaf $\mathrm{Zn}$ was $<50 \mu \mathrm{g} \cdot \mathrm{g}^{-1}$. No P was applied.

A completely randomized design was used with each treatment replicated six times ( 7 for K 1.00) in single-tree plots. Although the four thresholds progressed in units of $0.25 \% \mathrm{~K}$, the prescription nature of the applications makes them discontinuous; therefore, regression analysis was not appropriate. The statistical analysis was by SAS general linear models analysis of variance with mean separation by the PDIFF or TDIFF option ( $t$ test) (SAS Institute, 1989). An analysis of covariance adjusted yields for differences in tree circumference, but the results were similar to those for nonadjusted yields and are not presented except for the economic returns data of Table 3 .

\section{Results}

Potassium applied. Trees had liberal amounts of K applied in years preceding the initiation of the study. Soil test K in the top 15 $\mathrm{cm}$ was $\geq 112 \mathrm{~kg} \cdot \mathrm{ha}^{-1}$ for all treatments after the first year. A soil test concentration of 68 to $168 \mathrm{~kg} \cdot \mathrm{ha}^{-1}$ is medium for this soil. Soil K in the 15 to $30 \mathrm{~cm}$ layer was $\geq 75 \mathrm{~kg} \cdot \mathrm{ha}^{-1}$. Leaves from trees designated for K 0.25 never dropped below the threshold over the 20-year period and thus did not require K (Table 1). No tree of K 0.50 required $\mathrm{K}$ for the first 16 years. On year 17 , one tree; year 19 , four trees; and year 20, one tree of the six-tree replication required $\mathrm{K}$ to meet the treatment specifications of $\mathrm{K} 0.50$. An average of only $93 \mathrm{~kg} \cdot \mathrm{ha}^{-1}$ of $\mathrm{K}$ was needed for the 20 -year period. It took 9 years for the first two trees with the $\mathrm{K} 0.75$ threshold to require $\mathrm{K}$ and another 5 years for additional trees to need $\mathrm{K}$. The $\mathrm{K} 0.75$ threshold required $403 \mathrm{~kg} \mathrm{~K} /$ ha over the 20 -year period. The K 1.00 threshold did not require K in 1976 and 1978, but at least one tree required $\mathrm{K}$ in all other years. It was 12 years before all trees of $\mathrm{K}$ 1.00 required $\mathrm{K}$ in the same year. Over the 20 -year period, K 1.00 required $\approx 2.5$ times the $K$ required for $K 0.75$, but only half that of AK.

Yield and value. Even though $\mathrm{K}$ applications over the 20-year period ranged from 0 to $1860 \mathrm{~kg} \cdot \mathrm{ha}^{-1}$ for treatments, overall mean yield was very close and not significantly different between treatments (Table 2). The K 100 threshold yielded less than K 0.75 and AK in 1974 and 1988. No treatment yielded significantly more than $\mathrm{K} 0.25$ in any year. Yields were considered very good, averaging $1467 \mathrm{~kg} \cdot \mathrm{ha}^{-1} \cdot \mathrm{year}^{-1}$ through 1991, although alternate bearing was apparent. There was no yield from any of the trees in 1992. The value of the crop, determined from actual sales, was greatest for AK but was also not significantly different from the other treatments. When cost of $\mathrm{K}$ applied was deducted and yields were adjusted for tree circumference, K 0.75 was of greatest numerical value. Potassium was apparently sufficient for good pecan yields even when none was applied for 19 years.

Tree growth, crop density, and appearance. Tree circumference growth from 1973-92 ranged from 43 to $53 \mathrm{~cm}$ and terminal shoot growth ranged from 173 to $187 \mathrm{~cm}$ (data not shown) and was not affected by treatment. Crop density as measured by fruit per terminal and tree appearance as measured by vigor and color ratings were also similar for all treatments.

Nut quality. Nut quality as measured by percentage kernel and percentage of kernels grading fancy, standard, and amber and nut size as measured by nuts per kilogram and percentage of kernels in size categories were not affected by K treatments (data not shown).

Leaf analysis. Leaf $\mathrm{K}$ was relatively high for all treatments at the beginning of the study, and differences were not observed until the third year (Table 3). Residual K apparently kept leaf K concentrations relatively high in $\mathrm{K} 0.25$ throughout the study. It

Table 1. Average K applied per hectare to all pecan trees in a treatment for which applications were based on leaf K.

\begin{tabular}{|c|c|c|c|c|c|c|c|c|c|c|c|c|c|c|c|c|c|c|c|c|c|}
\hline \multirow{2}{*}{$\begin{array}{l}\text { Leaf } \mathrm{K}^{\mathrm{z}} \\
(\%)\end{array}$} & \multicolumn{20}{|c|}{ Potassium applied $\left(\mathrm{kg} \cdot \mathrm{ha}^{-1}\right)^{\mathrm{y}}$} & \multirow{2}{*}{$\begin{array}{l}\text { Cumulative } \\
\text { K applied }\end{array}$} \\
\hline & 1973 & 1974 & 1975 & 1976 & 1977 & 1978 & 1979 & 1980 & 1981 & 1982 & 1983 & 1984 & 1985 & 1986 & 1987 & 1988 & 1989 & 1990 & 1991 & 1992 & \\
\hline$\overline{\mathrm{K} 0.25}$ & $0 \mathrm{a}$ & $0 \mathrm{a}$ & $0 \mathrm{a}$ & $0 \mathrm{a}$ & $0 \mathrm{a}$ & $0 \mathrm{a}$ & $0 \mathrm{a}$ & $0 \mathrm{a}$ & $0 \mathrm{a}$ & $0 \mathrm{a}$ & $0 \mathrm{a}$ & $0 \mathrm{a}$ & $0 \mathrm{a}$ & $0 \mathrm{a}$ & $0 \mathrm{a}$ & $0 \mathrm{a}$ & $0 \mathrm{a}$ & $0 \mathrm{a}$ & $0 \mathrm{a}$ & $0 \mathrm{a}$ & 0 \\
\hline K 0.50 & $0 \mathrm{a}$ & $0 \mathrm{a}$ & $0 \mathrm{a}$ & $0 \mathrm{a}$ & $0 \mathrm{a}$ & $0 \mathrm{a}$ & $0 \mathrm{a}$ & $0 \mathrm{a}$ & $0 \mathrm{a}$ & $0 \mathrm{a}$ & $0 \mathrm{a}$ & $0 \mathrm{a}$ & $0 \mathrm{a}$ & $0 \mathrm{a}$ & $0 \mathrm{a}$ & $0 \mathrm{a}$ & $16 \mathrm{ab}$ & $0 \mathrm{a}$ & $62 b$ & $16 \mathrm{a}$ & 93 \\
\hline K 0.75 & $0 \mathrm{a}$ & $0 \mathrm{a}$ & $0 \mathrm{a}$ & $0 \mathrm{a}$ & $0 \mathrm{a}$ & $0 \mathrm{a}$ & $0 \mathrm{a}$ & $0 \mathrm{a}$ & $31 b$ & $0 \mathrm{a}$ & $0 \mathrm{a}$ & $0 \mathrm{a}$ & $0 \mathrm{a}$ & $46 \mathrm{~b}$ & $46 \mathrm{~b}$ & $62 \mathrm{~b}$ & $46 \mathrm{~b}$ & $0 \mathrm{a}$ & $93 \mathrm{c}$ & $77 \mathrm{~b}$ & 403 \\
\hline K 1.00 & $13 \mathrm{a}$ & $40 \mathrm{~b}$ & $13 \mathrm{a}$ & $0 \mathrm{a}$ & $13 \mathrm{a}$ & $0 \mathrm{a}$ & $53 \mathrm{~b}$ & $67 \mathrm{~b}$ & $62 \mathrm{c}$ & $46 \mathrm{~b}$ & $16 \mathrm{a}$ & $93 \mathrm{~b}$ & $52 \mathrm{~b}$ & $93 \mathrm{c}$ & $93 \mathrm{c}$ & $77 \mathrm{c}$ & $83 c$ & $93 \mathrm{~b}$ & $93 \mathrm{c}$ & $93 \mathrm{~b}$ & 1079 \\
\hline $\mathrm{AK}$ & $93 \mathrm{~b}$ & $93 \mathrm{c}$ & $93 \mathrm{~b}$ & $93 \mathrm{~b}$ & $93 \mathrm{~b}$ & $93 \mathrm{~b}$ & $93 \mathrm{c}$ & $93 \mathrm{~b}$ & $93 \mathrm{~d}$ & $93 \mathrm{c}$ & $93 \mathrm{~b}$ & $93 \mathrm{~b}$ & $93 \mathrm{c}$ & $93 \mathrm{c}$ & $93 \mathrm{c}$ & $93 \mathrm{c}$ & $93 \mathrm{c}$ & $93 \mathrm{~b}$ & $93 \mathrm{c}$ & $93 \mathrm{~b}$ & 1860 \\
\hline
\end{tabular}

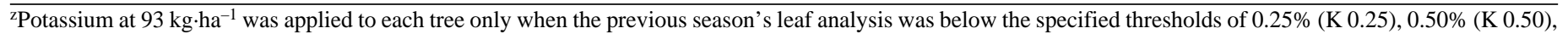
$0.75 \%$ (K 0.75), or $1.00 \%$ (K 1.00), except that treatment AK received $93 \mathrm{~kg} \cdot \mathrm{ha}^{-1}$ annually regardless of leaf analysis.

yMean separation within columns by GLM with PDIFF option at $P=0.05$.

${ }^{x}$ Values are least square means and thus may differ slightly from year sum. 
was 7 years before differences could be detected between $\mathrm{K} 0.25$ and AK. Leaf $\mathrm{K}$ was highest in AK thereafter in most years, but treatment differences were not significant in 1989 and 1991. Leaf K was higher for K 1.00 than for K 0.25 only in 1988 and 1990. The lack of differences in 1991 may have been caused by the large number of trees requiring $\mathrm{K}$ that year. The $\mathrm{K} 0.25$ threshold was the only treatment not requiring $\mathrm{K}$. The application quantities pre- sented are averages for all trees within a treatment, while applications were made on a per-tree basis. Once an application was made to an individual tree, the depletion process recommenced for that tree, probably accounting for some of the yearly variation. Note that leaf $\mathrm{K}$ for the annual treatment was above the suggested $1.25 \%$ lower threshold concentration in only 3 years. Leaf K dropped to concentrations suspected to show $\mathrm{K}$ deficiency symptoms only in

Table 2. Yield, value, and return for pecan nuts from 'Stuart' trees when K applications were based on leaf analysis.

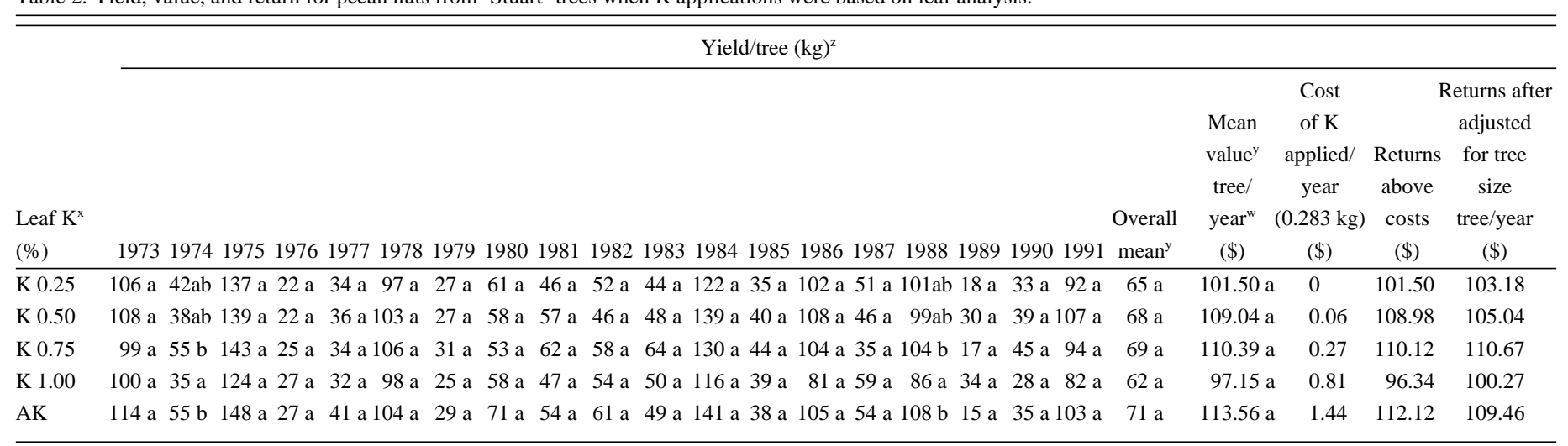

${ }^{\mathrm{z}}$ Mean separation within columns by GLM with PDIFF option at $P=0.05$.

yValues are least square means and thus may differ slightly from year sum.

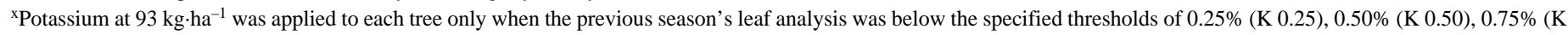
0.75 ), or $1.00 \%$ (K 1.00), except that treatment AK received $93 \mathrm{~kg} \cdot \mathrm{ha}^{-1}$ annually regardless of leaf analysis.

${ }^{w}$ Value assumes equal prices received per kilogram of kernel before 1978 and per kilogram of in-shell nuts thereafter for all treatments.

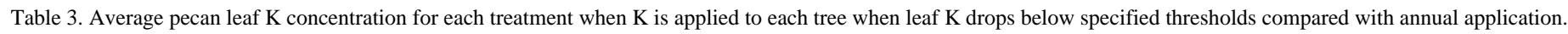

\begin{tabular}{|c|c|c|c|c|c|c|c|c|c|c|c|c|c|c|c|c|c|c|c|c|}
\hline \multirow{2}{*}{$\begin{array}{l}\text { Leaf } \mathrm{K}^{\mathrm{z}} \\
(\%)\end{array}$} & \multicolumn{20}{|c|}{ Leaf K (\%) } \\
\hline & 1973 & 1974 & 1975 & 1976 & 1977 & 1978 & 1979 & 1980 & 1981 & 1982 & 1983 & 1984 & 1985 & 1986 & 1987 & 1988 & 1989 & 1990 & 1991 & 1992 \\
\hline K 0.25 & $1.09 \mathrm{a}^{\mathrm{y}}$ & $1.46 \mathrm{a}$ & $1.17 \mathrm{~b}$ & $1.22 \mathrm{a}$ & $1.36 \mathrm{~b}$ & $0.98 \mathrm{a}$ & $1.03 \mathrm{a}$ & $0.85 \mathrm{a}$ & $1.05 \mathrm{a}$ & $1.31 \mathrm{~b}$ & $0.90 \mathrm{a}$ & $0.98 b c$ & $0.86 \mathrm{a}$ & $0.76 \mathrm{ab}$ & $0.87 \mathrm{ab}$ & $0.65 \mathrm{a}$ & $0.88 \mathrm{a}$ & $0.59 \mathrm{~b}$ & $0.89 \mathrm{a}$ & $0.68 \mathrm{ab}$ \\
\hline K 0.50 & $1.16 \mathrm{a}$ & $1.48 \mathrm{a}$ & $1.03 \mathrm{a}$ & $1.15 \mathrm{a}$ & $1.20 \mathrm{a}$ & $0.91 \mathrm{a}$ & $1.08 \mathrm{ab}$ & $0.86 \mathrm{a}$ & $0.99 \mathrm{a}$ & $1.19 \mathrm{ab}$ & $0.84 \mathrm{a}$ & $0.90 \mathrm{a}$ & $0.74 \mathrm{a}$ & $0.79 \mathrm{~b}$ & $0.78 \mathrm{ab}$ & $0.76 \mathrm{ab}$ & $0.82 \mathrm{a}$ & $0.45 \mathrm{a}$ & $0.71 \mathrm{a}$ & $0.51 \mathrm{a}$ \\
\hline K 0.75 & $1.05 \mathrm{a}$ & $1.32 \mathrm{a}$ & $1.03 \mathrm{a}$ & $1.16 \mathrm{a}$ & $1.29 \mathrm{ab}$ & $1.00 \mathrm{a}$ & $1.00 \mathrm{a}$ & $0.87 \mathrm{a}$ & $1.00 \mathrm{a}$ & $1.16 \mathrm{ab}$ & $0.87 \mathrm{a}$ & $0.91 \mathrm{a}$ & $0.79 \mathrm{a}$ & $0.72 \mathrm{a}$ & $0.76 \mathrm{a}$ & $0.77 \mathrm{ab}$ & $0.88 \mathrm{a}$ & $0.46 \mathrm{a}$ & $0.90 \mathrm{a}$ & $0.68 \mathrm{ab}$ \\
\hline K 1.00 & $1.00 \mathrm{a}$ & $1.32 \mathrm{a}$ & $0.99 \mathrm{a}$ & $1.10 \mathrm{a}$ & $1.24 \mathrm{ab}$ & $1.00 \mathrm{a}$ & $1.00 \mathrm{a}$ & $0.88 \mathrm{ab}$ & $1.01 \mathrm{a}$ & $1.10 \mathrm{a}$ & $0.87 \mathrm{a}$ & $0.99 \mathrm{c}$ & $0.78 \mathrm{a}$ & $0.75 \mathrm{ab}$ & $0.89 \mathrm{~b}$ & $0.81 b c$ & $0.76 \mathrm{a}$ & $0.71 \mathrm{c}$ & $0.92 \mathrm{a}$ & $0.74 \mathrm{bc}$ \\
\hline $\mathrm{AK}$ & $1.05 \mathrm{a}$ & $1.56 \mathrm{a}$ & $1.15 \mathrm{~b}$ & $1.22 \mathrm{a}$ & $1.36 \mathrm{ab}$ & $1.01 \mathrm{a}$ & $1.19 \mathrm{~b}$ & $1.00 \mathrm{~b}$ & $1.25 \mathrm{~b}$ & $1.23 \mathrm{ab}$ & $1.01 \mathrm{~b}$ & $1.07 \mathrm{~d}$ & $1.00 \mathrm{~b}$ & $0.91 \mathrm{c}$ & $1.06 \mathrm{c}$ & $0.95 \mathrm{c}$ & $0.82 \mathrm{a}$ & $0.93 \mathrm{~d}$ & $0.91 \mathrm{a}$ & $0.95 \mathrm{c}$ \\
\hline
\end{tabular}

y Mean separation within columns by GLM with PDIFF option at $P=0.05$.

Table 4. Average soil test K concentrations when K applications to pecans were based on leaf K concentration.

\begin{tabular}{|c|c|c|c|c|c|c|c|c|c|c|c|c|c|c|c|c|c|c|c|c|}
\hline \multirow{2}{*}{$\begin{array}{l}\text { Leaf } \mathrm{K}^{\mathrm{z}} \\
(\%)\end{array}$} & \multicolumn{20}{|c|}{ Soil concn $\left(\mathrm{kg} \cdot \mathrm{ha}^{-1}\right)^{\mathrm{y}}$} \\
\hline & 1973 & 1974 & 1975 & 1976 & 1977 & 1978 & 1979 & 1980 & 1981 & 1982 & 1983 & 1984 & 1985 & 1986 & 1987 & 1988 & 1989 & 1990 & 1991 & 1992 \\
\hline \multicolumn{21}{|c|}{$0-15 \mathrm{~cm}$ level } \\
\hline K 0.25 & $139 a$ & $130 \mathrm{a}$ & $152 \mathrm{~b}$ & $109 \mathrm{ab}$ & $146 \mathrm{a}$ & $166 \mathrm{bc}$ & $167 \mathrm{a}$ & $152 \mathrm{a}$ & $152 \mathrm{a}$ & $194 \mathrm{a}$ & $142 \mathrm{a}$ & $185 \mathrm{a}$ & $162 \mathrm{a}$ & $166 \mathrm{ab}$ & $128 \mathrm{ab}$ & $114 \mathrm{a}$ & $118 \mathrm{ab}$ & $127 \mathrm{a}$ & $120 \mathrm{a}$ & $139 \mathrm{a}$ \\
\hline K 0.50 & $112 \mathrm{a}$ & $103 \mathrm{a}$ & $127 \mathrm{a}$ & $88 \mathrm{a}$ & $100 \mathrm{a}$ & $148 \mathrm{a}$ & $155 \mathrm{a}$ & $148 \mathrm{a}$ & $144 \mathrm{a}$ & $193 \mathrm{a}$ & $131 \mathrm{a}$ & $190 \mathrm{a}$ & $157 \mathrm{a}$ & $148 \mathrm{a}$ & $116 \mathrm{a}$ & $109 \mathrm{a}$ & $109 \mathrm{a}$ & $112 \mathrm{a}$ & $90 \mathrm{a}$ & $131 \mathrm{a}$ \\
\hline K 0.75 & $112 \mathrm{a}$ & $122 \mathrm{a}$ & $140 \mathrm{ab}$ & $105 \mathrm{a}$ & $108 \mathrm{a}$ & $162 \mathrm{ab}$ & $169 \mathrm{ab}$ & $155 \mathrm{a}$ & $168 \mathrm{a}$ & $195 \mathrm{a}$ & $152 \mathrm{ab}$ & $192 \mathrm{a}$ & $168 \mathrm{a}$ & $172 \mathrm{ab}$ & $128 \mathrm{ab}$ & $153 \mathrm{ab}$ & $132 \mathrm{bc}$ & $132 \mathrm{ab}$ & $104 \mathrm{a}$ & $169 \mathrm{~b}$ \\
\hline K 1.00 & $130 \mathrm{a}$ & $116 \mathrm{a}$ & $151 \mathrm{ab}$ & $88 \mathrm{a}$ & $114 \mathrm{a}$ & $153 \mathrm{ab}$ & $169 \mathrm{ab}$ & $195 \mathrm{~b}$ & $168 \mathrm{a}$ & $183 \mathrm{a}$ & $133 \mathrm{a}$ & $199 \mathrm{ab}$ & $202 b$ & $159 \mathrm{a}$ & $150 \mathrm{bc}$ & $177 \mathrm{bc}$ & $144 \mathrm{c}$ & $160 \mathrm{bc}$ & $103 \mathrm{a}$ & $169 \mathrm{~b}$ \\
\hline $\mathrm{AK}$ & $138 \mathrm{a}$ & $119 \mathrm{a}$ & $151 \mathrm{~b}$ & $140 \mathrm{~b}$ & $164 \mathrm{a}$ & $181 \mathrm{c}$ & $195 \mathrm{~b}$ & $205 \mathrm{~b}$ & $212 b$ & 209 a & $175 b$ & $224 \mathrm{~b}$ & $233 \mathrm{c}$ & $187 \mathrm{~b}$ & $162 \mathrm{c}$ & $206 \mathrm{c}$ & $167 \mathrm{~d}$ & $174 \mathrm{c}$ & $108 \mathrm{a}$ & $174 \mathrm{~b}$ \\
\hline \multicolumn{21}{|c|}{$15-30 \mathrm{~cm}$ level } \\
\hline K 0.25 & $88 \mathrm{a}$ & $85 \mathrm{a}$ & $85 \mathrm{a}$ & --- & $60 \mathrm{a}$ & $109 \mathrm{~b}$ & $147 \mathrm{~b}$ & $106 \mathrm{a}$ & $118 \mathrm{ab}$ & $131 \mathrm{bc}$ & $103 \mathrm{~b}$ & $90 \mathrm{a}$ & $114 \mathrm{~b}$ & $141 \mathrm{~b}$ & $95 \mathrm{ab}$ & $100 a b$ & $83 a b$ & $80 \mathrm{ab}$ & $66 \mathrm{a}$ & $96 \mathrm{~b}$ \\
\hline К 0.50 & $78 a$ & $84 a$ & $68 \mathrm{a}$ & --- & $59 a$ & $88 \mathrm{a}$ & $105 \mathrm{a}$ & $86 a$ & 93 a & $106 \mathrm{a}$ & $81 \mathrm{a}$ & $84 a$ & 93 a & $101 \mathrm{a}$ & $85 \mathrm{a}$ & $76 a$ & $69 a$ & $64 \mathrm{a}$ & $65 \mathrm{a}$ & $74 \mathrm{a}$ \\
\hline K 0.75 & $75 a$ & $83 a$ & $78 \mathrm{a}$ & --- & $72 \mathrm{a}$ & $93 \mathrm{ab}$ & $118 \mathrm{a}$ & $91 \mathrm{a}$ & $124 \mathrm{~b}$ & $112 a b$ & $83 \mathrm{a}$ & $91 \mathrm{a}$ & $109 \mathrm{ab}$ & $115 \mathrm{a}$ & $106 \mathrm{ab}$ & $120 \mathrm{bc}$ & $99 \mathrm{bc}$ & $88 \mathrm{~b}$ & $80 \mathrm{a}$ & $83 a b$ \\
\hline K 1.00 & $76 a$ & $75 a$ & $86 a$ & --- & $64 \mathrm{a}$ & $90 \mathrm{a}$ & $108 \mathrm{a}$ & $112 \mathrm{a}$ & $142 b$ & $134 \mathrm{c}$ & $92 \mathrm{ab}$ & $122 \mathrm{~b}$ & $131 \mathrm{c}$ & $137 \mathrm{~b}$ & $118 \mathrm{~b}$ & $143 \mathrm{~cd}$ & $113 \mathrm{c}$ & $128 \mathrm{c}$ & $84 \mathrm{a}$ & $139 \mathrm{c}$ \\
\hline AK & $91 \mathrm{a}$ & $93 \mathrm{a}$ & $121 \mathrm{~b}$ & --- & $75 a$ & $137 \mathrm{c}$ & $153 \mathrm{~b}$ & $148 \mathrm{~b}$ & $178 \mathrm{c}$ & $152 \mathrm{c}$ & $142 \mathrm{c}$ & $156 \mathrm{c}$ & $158 \mathrm{~d}$ & $146 \mathrm{~b}$ & $142 \mathrm{c}$ & $158 \mathrm{~d}$ & $144 \mathrm{~d}$ & $134 \mathrm{c}$ & $80 \mathrm{a}$ & $133 \mathrm{c}$ \\
\hline
\end{tabular}

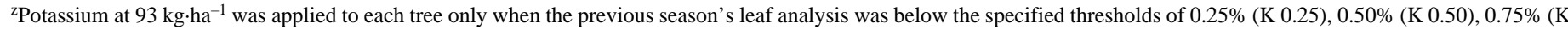
0.75 ), or $1.00 \%$ (K 1.00), except that treatment AK received $93 \mathrm{~kg} \cdot \mathrm{ha}^{-1}$ annually regardless of leaf analysis.

${ }^{y}$ Mean separation within columns by GLM with PDIFF option at $P=0.05$. 
1990 for the three lowest K thresholds. Averages for leaf K were within or close to the suggested adequate range in 1991. No K deficiency symptoms were noticed at any time during the study.

Leaf concentrations of $\mathrm{N}, \mathrm{P}, \mathrm{Ca}, \mathrm{Mg}, \mathrm{Mn}, \mathrm{Fe}$, and $\mathrm{Cu}$ were not affected consistently by the treatments. Mean leaf concentrations for treatments did not differ over the 1973-92 period for leaf $\mathrm{P}, \mathrm{Ca}$, $\mathrm{Mg}, \mathrm{Mn}, \mathrm{Cu}$, and $\mathrm{Zn}$. Leaf Fe was slightly lower for $\mathrm{K} 0.25$ than for other treatments, but the range was very narrow $\left(69\right.$ to $79 \mathrm{mg} \cdot \mathrm{g}^{-1}$ ). The mean leaf $\mathrm{N}$ was $2.74 \%$ to $2.81 \%$; therefore, differences were of little practical significance.

Soil analysis. Soil test $\mathrm{K}$ in the top $15 \mathrm{~cm}$ remained within or higher than the 68 to $168 \mathrm{~kg} \cdot \mathrm{ha}^{-1}$ range considered medium by the Georgia Soil Testing Laboratory for all treatments throughout the study, even when no K was applied (Table 4). Treatment differences did not segregate until the third year. The major difference thereafter was between $\mathrm{AK}$ and one of more of the other treatments, with differences among the other treatments usually being very small. Annual K addition did not cause a large buildup of available K in the soil. A soil test taken in Winter 1992-93 (residual from the 1992 season) after 20 years of application based on leaf analysis indicated equal soil $\mathrm{K}$ for $0.75,1.00$, and AK. Apparently, once the exchange capacity of the soil was met, the excess $\mathrm{K}$ from fertilizer was either lost by leaching or fixed in a nonavailable form. Soil $\mathrm{pH}, \mathrm{P}, \mathrm{Ca}$, and $\mathrm{Mg}$ were not affected significantly by treatment (Table 5).

Soil $\mathrm{K}$ in the 15 to $30 \mathrm{~cm}$ layer was of slightly lower magnitude than the top layer but reflected similar responses (Table 4 ). The $\mathrm{K}$ concentration was usually within or above the 68 to $168 \mathrm{~kg} \cdot \mathrm{ha}^{-1}$ range for all treatments throughout the test at this depth. Soil $\mathrm{pH}$ at the 15 to $30 \mathrm{~cm}$ depth after 20 years (Table 5) was increased slightly by $\mathrm{K}$ additions and was highest for $\mathrm{AK}$. There were no consistent differences in soil $\mathrm{P}, \mathrm{Ca}$, and $\mathrm{Mg}$, although the last year's 15 to 30 $\mathrm{cm}$ level indicated lower $\mathrm{Ca}$ and $\mathrm{Mg}$ concentrations at the $\mathrm{K} 0.50$ and K 0.75 thresholds than for AK (Table 5).

Extractable soil $\mathrm{P}$ was extremely high $\left[\left(\geq 254 \mathrm{~kg} \cdot \mathrm{ha}^{-1}\right)\right.$; concentrations $>67 \mathrm{~kg} \cdot \mathrm{ha}^{-1}$ are considered high for this soil by the Georgia Soil Testing Laboratory] in all plots even though none had been applied in 20 years, yet leaf concentrations $\left(0.13 \mu \mathrm{g} \cdot \mathrm{g}^{-1}\right)$ were not high. Although leaf $\mathrm{P}$ levels this low are not uncommon for trees in the field, they would be considered low based on greenhouse studies (Sparks, 1988). The P data supports the lack of relationship between extractable soil $\mathrm{P}$ and leaf $\mathrm{P}$ and the lack of a leaf response from applied $\mathrm{P}$.

\section{Discussion}

Many studies have been conducted on pecan trees during which specified rates of $\mathrm{K}$ were applied annually and the tree responses were measured. The grower who fertilizes by leaf analysis, however, is usually advised to apply a nutrient only when its leaf concentration drops below the sufficiency range. This is the only known report of $\mathrm{K}$ applied in this manner, and it supports the practice of fertilizing based on leaf analysis. Growers in Georgia are advised to apply $93 \mathrm{~kg} \cdot \mathrm{ha}^{-1}$ when leaf concentrations drop below $0.75 \%$, but for optimum production and tree vigor the concentrations should be maintained between $1.25 \%$ and $2.50 \%$ (Plank, 1988). This recommendation suggests that the lower threshold of $0.75 \%$ is too low. Reasons given for increasing the optimum concentration above $0.75 \%$ are to prevent cold injury and leaf scorch. Cold injury (that damages and kills trees at near ground line) is a problem only on young trees and would not be of concern on most old trees such as those in this study or in most producing orchards. In one report (Sharpe et al., 1952), late fall cold injury to 13-year-old 'Moore' trees was reduced by K applications, but leaf $\mathrm{K}$ concentrations were $0.45 \%$ to $0.48 \%$ for the trees to which no K was added. 'Stuart' and 'Moneymaker' trees were not injured. Cold damage was attributed to a loss of foliage in summer from scab and insects that induced a late flush of foliage that was immature when the temperature dropped to-7C on 25 Nov. Today, very few 'Moore' trees are grown; insect and disease control should prevent early defoliation and subsequent second flush growth and leaf $\mathrm{K}$ concentrations would not be expected to fall that low. The leaf scorch problem, once thought to be an N-K imbalance (Sparks, 1976), was not related to K application or leaf $\mathrm{K}$ concentration in a recent study (Worley, 1990b). No leaf scorch or cold injury was observed in this study.

There was no evidence from this study that $\mathrm{K}$ depletion had reached proportions that were detrimental to mature trees after 20 years without $\mathrm{K}$ applications. Yield and tree growth were excellent, and foliage color and vigor were good for all treatments. Nut quality was usually good, and quality differences could not be associated with $\mathrm{K}$ applications. Leaf $\mathrm{K}$ concentrations decreased below $0.75 \%$ in only 1 year, thus indicating that the lower threshold of $0.75 \%$ provides adequate $\mathrm{K}$. The data do not support a threshold lower than $0.75 \%$, because few of the trees were depleted below this concentration. Rapid depletion of $\mathrm{K}$ from an orchard is not expected, since a 454-kg crop of pecans removes only $1.5 \mathrm{~kg}$ of K (Hunter, 1956). Deficiency symptoms at $0.58 \%$ obtained in another study (Worley, 1974) suggest that a threshold much lower than $0.75 \%$ is probably too low. The $0.75 \%$ threshold seems to give adequate allowance for hidden deficiency and seems economically practical. This study did not justify the suggested $1.25 \% \mathrm{~K}$ lower threshold that would have called for $\mathrm{K}$ applications in all but 3 years, even when applications were already made annually. Once the trees were well supplied with $\mathrm{K}$, adding more $\mathrm{K}$ did not greatly increase the leaf $\mathrm{K}$ concentration.

Table 5. Soil test concentrations in Winter 1992-93 after 20 years of K application based on leaf analysis thresholds.

\begin{tabular}{|c|c|c|c|c|c|c|c|c|}
\hline \multirow{2}{*}{$\begin{array}{l}\text { Leaf } \mathrm{K}^{\mathrm{z}} \\
(\%)\end{array}$} & \multicolumn{4}{|c|}{$0-15 \mathrm{~cm} \mathrm{depth}^{\mathrm{y}}$} & \multicolumn{4}{|c|}{$15-30 \mathrm{~cm} \mathrm{depth}{ }^{\mathrm{x}}$} \\
\hline & $\mathrm{pH}$ & $\mathrm{P}$ & $\mathrm{Ca}$ & $\mathrm{Mg}$ & $\mathrm{pH}$ & $\mathrm{P}$ & $\mathrm{Ca}$ & $\mathrm{Mg}$ \\
\hline$\overline{\mathrm{K} 0.25}$ & $5.9 \mathrm{a}$ & $319 a$ & $2313 \mathrm{a}$ & $458 \mathrm{a}$ & $6.0 \mathrm{a}$ & $235 \mathrm{a}$ & $1581 \mathrm{~b}$ & $298 \mathrm{bc}$ \\
\hline К 0.50 & $5.8 \mathrm{a}$ & $304 \mathrm{a}$ & $2278 \mathrm{a}$ & $442 \mathrm{a}$ & $6.1 \mathrm{ab}$ & $221 \mathrm{a}$ & $1239 \mathrm{a}$ & $241 \mathrm{ab}$ \\
\hline K 0.75 & $5.9 \mathrm{a}$ & $254 \mathrm{a}$ & $2732 \mathrm{a}$ & $550 \mathrm{a}$ & $6.1 \mathrm{ab}$ & $253 \mathrm{a}$ & $1077 \mathrm{a}$ & $198 \mathrm{a}$ \\
\hline K 1.00 & $5.9 \mathrm{a}$ & $263 \mathrm{a}$ & 2539 a & $495 \mathrm{a}$ & $6.2 \mathrm{bc}$ & $186 \mathrm{a}$ & $1605 \mathrm{~b}$ & $310 \mathrm{c}$ \\
\hline $\mathrm{AK}$ & $5.8 \mathrm{a}$ & $301 \mathrm{a}$ & $2712 \mathrm{a}$ & $561 \mathrm{a}$ & $6.3 \mathrm{c}$ & $226 \mathrm{a}$ & $1641 \mathrm{~b}$ & $305 c$ \\
\hline
\end{tabular}

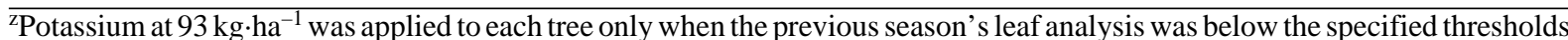
of $0.25 \%$ (K 0.25 ), $0.50 \%$ (K 0.50), $0.75 \%$ (K 0.75), or $1.00 \%$ (K 1.00), except treatment AK received $93 \mathrm{~kg} \cdot \mathrm{ha}^{-1}$ annually regardless of leaf analysis.

yPhosphorus, $\mathrm{K}, \mathrm{Ca}$, and $\mathrm{Mg}$ expressed as $\mathrm{kg} \cdot \mathrm{ha}^{-1}$.

${ }^{\mathrm{x}}$ Mean separation within columns by GLM with TDIFF option at $P=0.05$. 
The data confirm the feasibility of fertilizing with $\mathrm{K}$ based on leaf analysis. Growers who use leaf analysis save money on material and application costs. Growers who do not fertilize by leaf analysis normally apply $93 \mathrm{~kg} \mathrm{~K} / \mathrm{ha}$ annually. Omission of this application, if not needed, would then save the grower $\$ 32 /$ ha plus the cost of application. If all Georgia growers omitted one unnecessary application, it would save them almost \$2 million. Less fertilization also means less compaction caused by applicator trucks applying fertilizer to moist soils in the spring and less water pollution. Although the trees used in this study were large trees, previous studies (Worley, 1974, 1991) indicate that similar results could be expected from younger trees.

The DRIS concept for diagnosing nutrient deficiency is in its infancy for use with pecans. Many positive responses to nutrient application need to be documented for the DRIS method to be studied. Data from this study was included in calculating preliminary DRIS norms published earlier (Beverly and Worley, 1992). A suitable independent population from the literature was not identified to test the diagnostic accuracy of the norms.

\section{Literature Cited}

Beverly, R.B. and R.E. Worley. 1992. Preliminary DRIS diagnostic norms for pecan. HortScience 27:271.

Blackmon, G.H. 1936. Effects of fertilizers on the yield of pecan trees. Proc. Southeastern Pecan Growers Assn. 30:19-25.

Cahoon, G.A. 1974. Handbook on reference methods for soil testing. Council Soil Testing Plant Anal., Athens, Ga. p. 16-19, 35-40, 54-59.

Fowler, E.D., J.J. Skinner, and R.W. Ruprecht. 1933. Results of 10 years fertilizer experiments with pecans on Blanton fine sand and Bladen fine sandy loam. National Pecan Assn. Bul. 32:74-84.

Gammon, N., Jr., and R.H. Sharpe. 1959. Effect of five years of differential fertilization with nitrogen and potassium on the soil nutrients and on the mineral composition of Curtis pecan leaves. Proc. Southeastern Pecan Growers Assn. 52:57-65.

Hammar, H.E. and J.H. Hunter. 1948. The time factor in response of pecan trees to fertilizer applications. Proc. Southeastern Pecan Growers Assn. 41:36-43.

Horwitz, W. (ed.). 1980. Official methods of analysis of the association of agricultural chemists. 13th ed. Assn. of Offic. Agr. Chemists, Wash., D.C. Section 2058, p. 15.

Hunter, J.H. 1956. What is happening to nitrogen, phosphate, and potash in pecan orchard soils. Proc. Southeastern Pecan Growers Assn. 49:44-47.

Hunter, J.H. and H.E. Hammar. 1947. The results of applying different fertilizers to the Moore variety of pecan over a 10 year period. Proc.
Southeastern Pecan Growers Assn. 40:10-32.

Hunter, J.H. and H.E. Hammar. 1948. Nutritional deficiencies associated with poor filling of pecan nuts. Proc. Southeastern Pecan Growers Assn. 41:16-33.

Plank, C.O. 1988. Plant analysis handbook for Georgia. Ga. Coop. Ext. Serv. p. 48-49.

SAS Institute. 1989. SAS/STAT user's guide. version 6. 4th ed. vol. 2. SAS Institute, Cary, N.C.

Sharpe, R.H., G.H. Blackmon, and N. Gammon, Jr. 1950. Progress report of potash and magnesium fertilization of pecans. Proc. Southeastern Pecan Growers Assn. 43:86-89.

Sharpe, R.H., G.H. Blackmon, and N. Gammon, Jr. 1952. Relation of potash and phosphate fertilization to cold injury of Moore pecans. Proc. Southeastern Pecan Growers Assn. 45:81-84.

Skinner, J.J. 1921. Soil fertility and fertilizer problems in pecan culture. Proc. National Nut Growers Assn. 20:25-37.

Skinner, J.J. 1922. Influence of fertilizers on the yield, size, and quality of pecans. Proc. Georgia-Florida Pecan Growers Assn. 16:50-56.

Skinner, J.J. 1923. Management and fertilization of pecan soils. Proc. National Pecan Growers Assn. 22:123-133.

Skinner, J.J. 1926. Pecan soils and their fertilization. Proc. National Pecan Growers Assn. 25:54-65.

Skinner, J.J. 1927. The work of the Bureau of Chemistry and Soils with pecans. The relation of soil fertility and commercial fertilizers to pecan production. Proc. National Pecan Assn. 30:26-29.

Skinner, J.J. and R.W. Ruprecht. 1926. Results of fertilizer experiments with pecans in the Jacksonville section. Proc. Georgia-Florida Pecan Growers Assn. 20:24-32.

Smith, M.W., P.L. Ager, and D.S.W. Endicott. 1985. Effect of nitrogen and potassium on yield, growth and leaf elemental concentration of pecan. J. Amer. Soc. Hort Sci. 110:446-450.

Sparks, D. 1976. Nitrogen scorch and the pecan. Pecan South 3:500-501.

Sparks, D. 1988. Growth and nutritional status of pecans in response to phosphorus. J. Amer. Soc. Hort. Sci. 113:850-859.

Upson, J.R. and D. Sparks. 1969. Growth responses of one year old pecan seedlings, Carya illinoensis, Koch, in sand culture to various levels of potassium. J. Amer. Soc. Hort. Sci. 94:125-127.

Worley, R.E. 1974. Effect of N, P, K, and lime on yield, nut quality, tree growth and leaf analysis of pecan (Carya illinoensis W.). J. Amer. Soc. Hort. Sci. 99:49-57.

Worley, R.E. 1990a. Long-term performance of pecan trees when nitrogen application is based on prescribed threshold concentrations in leaf tissue. J. Amer. Soc. Hort. Sci. 115:745-749.

Worley, R.E. 1990b. Pecan leaf scorch in response to various combinations of nitrogen and potassium fertilization. HortScience 25:422-423. Worley, R.E. 1991. Pecan [Carya Illinoensis (Wangenh.) C. Koch] yield, leaf and soil analysis responses from different combinations of nitrogen and potassium application. Commun. Soil Sci. Plant Anal. 22:1919-1930. 